\title{
PENERAPAN METODE EKSPERIMEN TERHADAP PEMAHAMAN KONSEP SISWA KELAS VPADA MATERI GAYA DAN PEMANFATANNYA
}

\author{
Yuyu Hendawati ${ }^{1}$, Cici Kurniati ${ }^{2}$ \\ yuyuhendawati@upi.edu,cici.kurniati.@student.upi.edu
}

\begin{abstract}
ABSTRAK
Penelitian ini dilatarbelakangi oleh rendahnya pemahaman konsep siswa mengenai materi gaya dalam pelajaran IPA. Hal ini dikarenakan metode pembelajaran yang digunakan kurang bervariasi dan tidak menggunakan media dalam pembelajaran. Siswa hanya mendengarkan penjelasan dari guru, akibatnya siswa kesulitan dalam memahami materi pelajaran yang disampaikan sehingga pencapaian hasil belajar masih rendah. Tujuan penelitian ini untuk meningkatkan pemahaman konsep siswa pada materi gaya dan mengetahui aktivitas yang terjadi selama pembelajaran dengan menerapkan metode eksperimen. Metode yang digunakan dalam penelitian ini adalah penelitian tindakan kelas dengan mengadaptasi desain penelitian Kemmis dan Mc. Taggart. Penelitian dilaksanakan dalam dua siklus. Setiap siklus terdiri dari empat tahap kegiatan yaitu, perencanaan, tindakan, observasi, dan refleksi. Subjek penelitian adalah siswa kelas V SDN Legokhuni dengan jumlah 30 orang. Pengumpulan data dalam penelitian ini menggunakan tes dan observasi. Berdasarkan data hasil penelitian dengan menerapkan metode eksperimen diperoleh hasil yang cukup memuaskan. Hal ini dapat dilihat dari persentase ketuntasan klasikal yang mengalami peningkatan. Pada siklus I sebesar $66,7 \%$ meningkat menjadi $86,7 \%$ pada siklus II. Selain itu aktivitas siswa dalam proses pembelajaran juga mengalami peningkatan pada setiap siklusnya. Dari data di atas, disimpulkan bahwa pembelajaran IPA di SD dengan menerapkan metode eksperimen dapat meningkatkan pemahaman konsep dan aktivitas belajar siswa.
\end{abstract}

Kata Kunci: Metode Eksperimen, Pemahaman Konsep, Gaya dan Pemanfaatannya

\section{A. PENDAHULUAN}

Ilmu Pengetahuan Alam (IPA) adalah salah satu mata pelajaran yang diajarkan di sekolah dasar. Mempelajari IPA tidak hanya sekedar menghafal, tetapi juga harus memahami konsep-konsep materi pelajaran.

Berdasarkan hasil tes awal
pemahaman konsep siswa pada pembelajaran IPA tentang gaya, yang dilakukan pada siswa kelas $\mathrm{V}$ dengan jumlah 30 orang, diperoleh nilai rata-rata 54. Nilai ini masih jauh dari yang diharapkan yaitu berdasarkan KKM yang ditetapkan sekolah sebesar 69 , hanya 7 siswa $(23,3 \%)$ yang tuntas dari jumlah keselurahan siswa kelas $\mathrm{V}$ sebanyak 30 Orang.

Kondisi ini terjadi karena siswa kesulitan dalam memahami materi pelajaran. Pembelajaran yang biasa dilakukan masih belum dapat mengembangkan pemahaman konsep 
siswa. Metode pembelajaran yang digunakan kurang bervariasi dan tidak menggunakan media pembelajaran. Siswa hanya duduk mendengarkan penjelasan dari guru, akibatnya siswa kurang dapat memahami materi pelajaran yang disampaikan dan perolehan nilai hasil belajar siswa pun rendah.

Salah satu cara mengajar guru yang dapat membantu siswa memahami konsep dari materi yang diajarkan yaitu dengan belajar bermakna, artinya dengan cara mempraktekkan langsung materi yang diajarkan. Sesuai dengan sebuah pendapatyang menyatakan bahwa IPA membahas tentang gejala-gejala alam yang disusun secara sistematis berdasarkan pada hasil percobaan dan pengamatan yang dilakukan oleh manusia (Samatowa, 2010, hlm. 03). Dengan kata lain, IPA tidak dapat dipisahkan dari percobaan dan pengamatan.

Salah satu alternatif untuk membantu siswa memahami konsep materi IPA tentang gaya dan pemanfaatnannya adalah dengan menngunakan metode eksperimen dalam pembelajaran.

Roestiyah (2008, hlm. 80) mengemukakan bahwa metode eksperimen ialah cara mengajar, di mana siswa melakukan percobaan tentang sesuatu hal, diamati prosesnya, laludituliskan hasil percobaan tersebut, kemudian hasilnya dipresentasikan di kelas dan dilakukan evaluasi oleh guru. Sehingga dengan melakukan eksperimen, siswa lebih mudah memahami konsep apa yang dipelajari karena mengalami sendiri sesuatu yang sedang dipelajarinya. Adapun tahapan-tahapan pelaksanaan metode eksperimen menurut Palendeng (dalam Hamdayama, 2014, hlm. 126) sebagai berikut: 1) percobaan awal, 2) pengamatan, 3) hipotesis awal, 4) verifikasi/ melakukan percobaan, dan 5) evaluasi.

Dengan menerapkan metode eksperimen akan melatih dan mengajarkan siswa dalam belajar suatu konsep materi yang dipelajari. Siswa terlibat aktif dalam pembelajaran dengan mengikuti tahapan-tahapan pembelajaran. Sehingga, siswa dapat menemukan sendiri tentang konsep yang sedang dipelajarinya sesuai dengan yang diperoleh dalam pembelajaran.

\section{B. KAJIAN TEORITIK}

1. Metode Eksperimen

Metode eksperimen menurut Sagala (2005, hlm. 220) adalah "Cara penyajian pelajaran yang mengarahkan siswa untuk melakukan percobaan dengan mengalami sendiri apa yang sedang dipelajarinya. Metode eksperimen mampu menciptakan kondisi belajar yang dapat mengembangkan kemampuan berpikir dan kreativitas siswa secara optimal".

Sedangkan Djamarah dan Zain (2006, hlm. 84) mengungkapkan bahwa, metode eksperimen adalah cara penyajian pelajaran, dimana siswa melakukan percobaan dengan mengalami dan membuktikan sendiri sesuatu yang dipelajari. Dalam proses pembelajaran dengan metode eksperimen ini, siswa diberi kesempatan untuk mengalami sendiri atau melakukan sendiri, mengikuti suatu proses, mengamati suatu objek, menganalisis, membuktikan dan menarik kesimpulan sendiri mengenai suatu objek, keadaan atau proses sesuatu. Dengan demikian, siswa dituntut untuk mengalami sendiri, mencari kebenaran, atau mencoba mencari suatu hukum atau dalil, dan menarik kesimpulan atas proses yang dialaminya itu.

Berdasarkan pengertian di atas, dapat ditarik kesimpulan bahwa metode eksperimen adalah metode belajar mengajar yang sesuai untuk pembelajaran IPA dengan memberikan kondisi belajar kepada siswa agar dapat mengembangkan kemampuan berpikir dan kreativitas secara optimal.

Tujuan metode eksperimen yaitu agar siswa mampu mencari dan 
menemukan sendiri berbagai jawaban atau persoalan-persoalan yang dihadapinya dengan mengadakan percobaan sendiri. Juga siswa dapat terlatih dalam cara berfikir yang ilmiah. Dengan eksperimen siswa menemukan bukti kebenaran dari teori sesuatu yang sedang dipelajarinya.

Langkah-langkah eksperimen yang dikemukakan Ramyulis (2005, hIm. 250) sebagai berikut:

1) memberi penjelasan secukupnya tentang apa yang harus dilakukan dalam eksperimen; 2) menentukan langkahlangkah pokok dalam membantu siswa dengan eksperimen; 3) sebelum eksperimen di laksanakan terlebih dahulu guru harus menetapkan: alat-alat apa yang diperlukan, langkah-langkah apa yang harus ditempuh, hal-hal apa yang harus dicatat, dan variabel-variabel mana yang harus dikontrol; dan 4) setelah eksperimen dilakukan guru harus menentukan tindak lanjut eksperimen contohnya : mengumpulkan laporan mengenai eksperimen tersebut, mengadakan tanya jawab tentang proses, melaksanakan teks untuk menguji pengertian siswa.

Menurut Winataputra (Tsuraya, 2013, hlm. 9) "Karakteristik metode eksperimen serta hubungannya dengan pengalaman belajar siswa, yaitu: 1) ada alat bantu yang digunakan; 2 ) ada tempat untuk melakukan metode eksperimen; 3 ) ada pedoman (petunjuk kerja) untuk siswa; 4) ada topik (materi pelajaran) yang dieksperimenkan; dan 5) ada temuantemuan".

Menurut Djamarah dan Zain (2006,

hlm. 84) kelebihan metode eksperimen adalah sebagai berikut:

(1) Membuat siswa lebih percaya atas kebenaran atau kesimpulan berdasarkan percobaannya; (2) Dapat membina siswa untuk membuat terobosan-terobosan baru dengan penemuan dari hasil percobaannya dan bermanfaat bagi kehidupan manusia; (3) Hasil-hasil percobaan yang berharga dapat dimanfaatkan untuk kemakmuran umat manusia.

Sedangkan kekurangan dari metode eksperimen menurut Djamarah dan Zain (2006, hlm. 84), yaitu:

(1) Metode ini lebih sesuai untuk bidangbidang sains dan teknologi; (2) Metode ini memerlukan berbagai fasilitas peralatan dan bahan yang tidak selalu mudah diperoleh dan mahal; (3) Metode ini menuntut ketelitian, keuletan, dan katabahan; (4) Setiap percobaan tidak selalu memberikan hasil yang diharapkan karena mungkin ada faktor-faktor tertentu yang berada diluar jangkauan kemampuan atau pengendalian.

2. Pemahaman Konsep

a. Pengertian Pemahaman Konsep

Bloom (Widodo, 2006, hlm. 6) mengemukakan bahwa, 'comprehension is understand the meaning, paraphrase a concept'. Siswa dapat memahami ketika mereka mampu membuat hubungan antara pengetahuan baru untuk ditambahkan dan pengetahuan sebelumnya. Pengetahuan yang masuk didintegrasikan dengan model mental dan kerangka kognitif yang ada. Pengetahuan konseptual memberikan dasar untuk sebuah pemahaman. Berdasarkan taksonomi Bloom, pemahaman merupakan jenjang kognitif $\mathrm{C}_{2}$.

b. Indikator Pemahaman Konsep.

Anderson dan Krathwohl (2010, hlm. 106) mengemukakan bahwa, “... dalam kategori memahami mencakup tujuh proses kognitif, meliputi: menafsirkan (interpreting), memberikan contoh (exemplifying), mengklasifikasikan (classifying), meringkas (summarizing), menarik inferensi/ menyimpulkan (inferring), membandingkan (comparing), dan menjelaskan (explaining)". 
(1). Menafsirkan (interpreting), yaitu mengubah dari suatu bentuk informasi ke bentuk informasi lainnya, misalnya dari kata-kata ke grafik atau gambar, atau sebaliknya, dari kata-kata ke angka, atau sebaliknya, maupun dari kata-kata ke kata-kata, misalnya meringkas atau membuat paraphrase; 2) Memberikan contoh (exemplifying), yaitu memberikan contoh dari suatu konsep atau prinsip yang bersifat umum. Memberikan contoh menuntut kemampuan mengidentifikasi ciri khas suatu konsep dan selanjutnya menggunakan ciri tersebut untuk membuat contoh; 3) Mengklasifikasikan (classifying), yaitu mengenali bahwa sesuatu (benda atau fenomena) masuk dalam kategori tertentu; 4) Meringkas (summarizing), yaitu membuat suatu pernyataan yang mewakili seluruh informasi atau membuat suatu abstrak dari sebuah tulisan; 5) Menarik inferensi (inferring), yaitu menemukan suatu pola dari sederetan contoh atau fakta; 6) Membandingkan (comparing), yaitu mendeteksi persamaan dan perbedaan yang dimiliki dua objek, ide ataupun situasi; dan 7) Menjelaskan (explaining), yaitu mengkonstruk dan menggunakan model sebab-akibat dalam suatu sistem.

\section{c. Materi Gaya dan Pemanfaatannya}

Berdasarkan Kurikulum Tingkat Satuan Pendidikan 2006 (KTSP 2006) dengan Standar Kompetensi (SK) Memahami hubungan antara gaya, gerak, dan energi, serta fungsinya. Pada Kompetensi Dasar (KD) Mendeskripsikan hubungan antara gaya, gerak dan energi melalui percobaan pada kelas V SD.

\section{METODE}

Penelitian tindakan ini dikembangkan dengan menerapkan metode Penelitian Tindakan Kelas (PTK). Desain penelitian digunakan adalah desain penelitian yang dilakukan oleh Kemmis dan Mc. Taggart yang terdiri dari empat komponen, yaitu perencanaan, tindakan, observasi, dan refleksi. Keempat komponen tersebut dianggap sebagai satu siklus.

Penelitian dilakukan di SDN Legokhuni, Kecamatan Wanayasa, Kabupaten Purwakarta. Subjek penelitian yaitu siswa kelas $\mathrm{V}$ berjumlah 30 siswa dengan komposisi 13 siswa laki-laki dan 17 siswa perempuan.

Penelitian ini, menggunakan dua jenis instrumen, yaitu instrumen pembelajaran dan instrumen pengumpul data. Instrumen pembelajaran terdiri dari RPP dan Lembar Kerja Kelompok (LKK). Sedangkan instrumen pengumpul data, terdiri dari lembar observasi dan juga lembar tes.

Pengumpulan data dilakukan dengan observasi dan tes.Observasi dilakukan saat berlangsungnya kegiatan pembelajaran untuk mengukur aktivitas belajar siswa dan kinerja guru ketika menggunakan metode eksperimen. Sedangkan, tes dilakukan sebanyak 2 kali dalam setiap siklus yaitu sebelum proses pembelajaran menggunakan metode eksperimen (pretes) dan evaluasi setelah proses pembelajaran dengan menggunakan metode eksperimen (postes).

Analisis data dalam penelitian ini dilakukan dengan mengolah data yang berasal dari lembar observasi dan lembar tes. Langkah analisis data dilakukan sebagai berikut:

1. Data hasil observasi aktivitas siswa dan guru, didapat dengan pemberian skor pada lembar observasi. Skor yang digunakan adalah skala likert: $1=$ tidak baik, 2 = kurang baik, 3 = cukup baik, 4 = kurang baik, dan 5 = sangat baik. (Sugiyono, 2009, hlm.137)

Kemudian data skor yang diperoleh dihitung persentasenya dengan rumus berikut:

$$
N=\frac{\text { nilai yang diperoleh }}{\text { nilai maksimal }} \times 100 \%
$$

Keterangan:

(Sudjana, 2006, hlm. 78)

$$
10 \%-29 \%=\text { Sangat kurang }
$$




$$
\begin{array}{ll}
30 \%-49 \% & =\text { Kurang } \\
50 \%-69 \% & =\text { Cukup } \\
70 \%-89 \% & =\text { Baik } \\
90 \%-100 \% & =\text { Baik sekal }
\end{array}
$$

Apabila persentase observasi telah mencapai $70 \%$ ke atas, maka tujuan pembelajaran telah berhasil dicapai.

2. Data hasil tes pemahaman konsep siswa, dihitung sebagai berikut.

$$
\text { Nilai akhir }=\frac{\text { skor yang diperoleh }}{\text { skor ideal }} \times 100
$$

$$
\text { (Aqib, dkk., 2010, hlm. 40) }
$$

Siswa dikatakan tuntas belajarnya apabila mencapai KKM yang ditentukan sekolah sebesar 69. Selain menghitung skor total, dihitung pula nilai rata-rata hasil tes siswa menggunakan rumus berikut:

$X=\frac{\Sigma x}{N} \quad$ (Aqib, dkk., 2010, hlm. 40)

Keterangan:

$X=$ Nilai rata-rata

$\Sigma x=$ jumlah nilai seluruh siswa

$\mathrm{N}=$ Jumlah siswa

Untuk menghitung ketuntasan belajar siswa secara klasikal dapat menggunakan cara sebagai berikut:

$$
\begin{aligned}
& P \\
& \times 100 \%
\end{aligned}
$$$$
\text { (Aqib, dkk., 2010, hlm. 40) }
$$

Ketuntasan belajar klasikal dinyatakan berhasil apabila persentase ketuntasan mencapai $\geq 85 \%$.

\section{HASIL DAN PEMBAHASAN}

\section{A. Deskripsi Pelaksanaan Tindakan}

Pelaksanaan tindakan berupa implementasi tindakan-tindakan yang telah direncanakan sebelumnya berkaitan dengan metode eksperimen dalam meningkatkan pemahaman konsep. Sebelum melakukan penelitian, langkah pertama yang dilakukan adalah melakukan wawancara dengan guru kelas $\mathrm{V}$ dan observasi untuk mengetahui data awal penelitian yang dilakukan pada tanggal 12 April 2016 di SDN Legokhuni.

Pada data awal didapat hasil observasi dan wawancara diketahui bahwa pembelajaran IPA tentang materi gaya di kelas $V$ SDN Legokhuni belum menerapkan metode pembelajaran yang bervariasi. Cara mengajar guru hanya dengan metode ceramah yang didominasi oleh guru, lalu diselingi dengan tanya jawab. Setelah itu, siswa mengerjakan soal latihan yang dibuat guru. Siswa belum terlibat aktif dalam pembelajaran, karena hanya duduk, dengar, catat, dan diam. Siswa cpat bosan dan kurang fokus pada

\begin{tabular}{|c|c|c|c|c|}
\hline $\begin{array}{c}\text { No } \\
\text {. }\end{array}$ & $\begin{array}{c}\text { KK } \\
M\end{array}$ & $\begin{array}{c}\text { Juml } \\
\text { ah } \\
\text { Sisw } \\
\text { a }\end{array}$ & $\begin{array}{c}\text { Persent } \\
\text { ase }\end{array}$ & $\begin{array}{c}\text { Persenta } \\
\text { se } \\
\text { Ketuntas } \\
\text { an }\end{array}$ \\
\hline 1. & $<69$ & 23 & $76,7 \%$ & \multirow{4}{*}{$23,3 \%$} \\
\hline 2. & $=69$ & 0 & $0 \%$ & \\
\hline 3. & $>69$ & 7 & $23,3 \%$ & \\
\hline & alah & 30 & $100 \%$ & \\
\hline Ket & $\begin{array}{l}\text { rang } \\
\mathrm{n}\end{array}$ & \multicolumn{3}{|c|}{ Belum Tuntas } \\
\hline
\end{tabular}
pelajaran. Hal ini berakibat pada kurangnya pemahaman siswa pada pembelajaran IPA tentang konsep gaya. Hasil prestes pemahaman konsep gaya siswa kelas V SDN Legokhuni sebelum tindakan disajikan dalam Tabel 1.

Tabel 1. Persentase Hasil Pretes Siswa

Berdasarkan Tabel 1. Dapat diketahui bahwa sebelum dilakukan tindakan, dari 36 siswa kelas $\mathrm{V}$ SDN Legokhuni yang mempu mencapai KKM 69 hanya 7 siswa atau $23,3 \%$. Sedangkan yang belum mencapai KKM sebanyak 23 siswa atau $76,7 \%$. 
B. Temuan Pelaksanaan Tindakan

1. Siklus I

Pelaksanaan siklus I dilaksanakan pada hari Senin, tanggal 18 April. Pokok bahasan gaya pada siklus I ini adalah tentang gaya gravitasi, dengan tahapan sebagai berikut:

a. Tahap Perencanaan

Sebelum diadakan pembelajaran terlebih dahulu dibuat perencanaan sebagai berikut:

1) Menyusun Rencana Pelaksanaan Pembelajaran (RPP). RPP dibuat berdasarkan silabus dengan mengacu kepada SK, KD, dan Indikator tentang gaya gravitasi.

2) Mempersiapkan instrumen penelitian yang akan digunakan, diantaranya: Lembar observasi aktivitas siswa maupun guru, lembar kerja kelompok yang digunakan pada saat siswa melakukan percobaan, dan lembar tes pemahaman berupa soal pilihan ganda yang dibuat sesuai indikator pemahaman konsep yang diukur dalam penelitian ini, yaitu menjelaskan, memberikan contoh, menafsirkan, membandingkan, dan menyimpulkan.

3) Mempersiapkan sumber, bahan ajar, dan media yang sesuai dengan pokok bahasan gaya gravitasi.

b. Pelaksanaan Tindakan Siklus I

Pelaksanaan penelitian tindakan kelas siklus I dilaksanakan hari Senin, 18 April 2016 dimulai pukul $07.20 \mathrm{~s} / \mathrm{d} 08.30$ WIB.Materi yang dibahas yaitu konsep gaya gravitasi dengan menerapkan metode eksperimen.

1) Kegiatan Awal

Pada kegiatan awal, pembelajaran dibuka oleh guru dengan kegiatan berdo'a dan absensi.Kemudian siswa dikondisikan untuk memulai pembelajaran. Guru melakukan apersepsi untuk menggali pengetahuan awal siswa yang berkaitan dengan gaya gravitasi. Lalu guru menyampaikan tujuan pembelajaran yang akan dicapai hari itu yaitu memahami konsep tentang gaya gravitasi dan pemanfaatannya dalam kehidupan seharihari.

2) Kegiatan Inti

a) Tahap pecobaan awal, guru melakukan demonstrasi untuk menampilkan masalah yang berkaitan dengan materi IPA yang akan dipelajari.

b) Tahap pengamatan, siswa mengamati demonstrasi guru.

c) Tahap hipotesis awal, yaitu siswa diharapkan merumuskan hipotesis awal dari masalah yang didemonstrasikan guru.

d) Tahap verifikasi/ melakukan percobaan, pada tahap ini siswa bekerja dalam kelompoknya masing-masing untuk melakukan eksperimen dengan mengikuti langkah-langkah yang terdapat dalam LKK, mengamati percobaan yang dilakukan, menjawab pertanyaan arahan dalam LKK, dan membuat kesimpulan dari hasil percobaan yang dilakukan. Guru mengawasi dan membimbing siswa dalam melakukan eksperimen, sambil mengisi format penilaian observasi yang telah disiapkan. Setelah LKK selesai dikerjakan, guru memberikan kesempatan kepada setiap perwakilan kelompok untuk melaporkan hasil percobaannya.

e) Tahap evaluasi, guru memberikan postes kepada setiap individu. Nilai tes tersebut nantinya dijadikan sebagai bahan untuk merefleksi pembelajaran yang telah dilaksanakan untuk perbaikan pada siklus berikutnya.

3) Kegiatan Akhir

Guru dan siswa bersama-sama menyimpulkan materi yang telah dipelajari, memberi penguatan positif, dan berdoa bersama untuk menutup pembelajaran.

c. Observasi Tindakan Siklus I 
Berdasarkan observasi pada tindakan siklus I diperolah data aktivitas siswa dengan menerapkan metode eksperimen yaitu sebagai berikut: serius dalam mengikuti pembelajaran $70 \%$, mengamati demonstrasi guru $70,7 \%$, mengajukan pertanyaan 57,3\%, mengutarakan jawaban, 59,3\%, aktif berpartisipasi dalam kelompok $69,3 \%$, melakukan eksperimen sesuai dengan langkah kerja 69,3\%, menggunakan media pembelajaran $66 \%$, mengamati percobaan yang dilakukan $65,3 \%$, aktif berdiskusi dalam kelompok $66 \%$, dan mengerjakan tes secara individu 74,7\%. Berdasarkan data tersebut, nilai rata-rata keseluruhan aktivitas siswa dengan menerapkan metode eksperimen mencapai 66,8\% artinya termasuk dalam kategori cukup. Sedangkan, nilai pemahaman konsep siswa setelah penerapan metode eksperimen pada siklus I diuraikan sebagai berikut: indikator pemahaman menjelaskan tercapai $70 \%$, indikator mencontohkan tercapai $70 \%$, indikator menafsirkan tercapai $58,3 \%$, indikator membandingkan tercapai $73,3 \%$ dan indikator menyimpulkan tercapai $76,7 \%$. Dari hasil postes pemahaman konsep pada siklus I sudah memperoleh hasil yang cukup baik, hanya masih ada satu indikator pemahaman yang pencapaiannya kurang dari $70 \%$.

Adapun nilai rata-rata hasil tes pemahaman konsep setelah menggunakan metode eksperimen pada siklus I adalah sebesar 68,3 dengan ketuntasan klasikal sebeesar $66,7 \%$.Sementara itu, hasil pengamatan yang dilakukan untuk mengukur kinerja guru pada siklus I ini termasuk kategori cukup dengan persentase $69,3 \%$ sehingga masih perlu perbaikan pada siklus selanjutnya.

\section{d. Refleksi Siklus I}

Berdasarkan hasil tes dan observasi pada siklus I, diperoleh hasil refleksi dan analisis sebagai berikut: siswa belum sepenuhnya berpartisipasi aktif di dalam pembelajaran, beberapa siswa masih kesulitan dalam menyelesaikan soal tes pemahaman, dan siswa masih kurang dalam aspek mengajukan atau menjawab pertanyaan. Sehingga dapat disimpulkan bahwa dalam pelaksanaan pembelajaran dengan menggunakan metode eksperimen sudah terjadi peningkatan dibandingkan dengan sebelum adanya tindakan, akan tetapi nilai pencapaian aktivitas siswa dan guru serta hasil tes pemahaman konsep siswa belum mencapai target yang direncanakan sehingga masih perlu dilakukan perbaikan pada siklus II.

\section{Siklus II}

Siklus II dilaksanakan pada hari Rabu, tanggal 27 April. Kegiatan pembelajaran pada siklus II merupakan upaya perbaikan dari siklus sebelumnya. Pokok bahasan gaya pada siklus ke-II ini adalah tentang gayagesek, dengan tahapan sebagai berikut:

a. Tahap Perencanaan

1) Menyusun RPP perbaikan untuk pembelajaran pada siklus II. RPP dibuat berdasarkan silabus dengan mengacu kepada SK, KD, dan Indikator tentang gayagesek.

2) Mempersiapkan instrumen penelitian yang akan digunakan, diantaranya: Lembar observasi aktivitas siswa maupun guru, lembar kerja kelompok yang digunakan pada saat siswa melakukan percobaan, dan lembar tes pemahaman berupa soal pilihan ganda yang dibuat sesuai indikator pemahaman konsep yang diukur dalam penelitian ini, yaitu menjelaskan, memberikan contoh, menafsirkan, membandingkan, dan menyimpulkan.

3) Mempersiapkan sumber, bahan ajar, dan media yang sesuai dengan pokok bahasan gayagesek.

b. Pelaksanaan Tindakan Siklus II

Penelitian siklus II dilaksanakan hari Rabu, 27 April 2016. Materi yang dibahas yaitu konsep gaya gesek dengan menerapkan metode eksperimen. Adapun 
proses kegiatannya adalah sebagai berikut:

1) Kegiatan Awal

Kegiatan awal, pembelajaran dibuka oleh guru dengan kegiatan berdo'a dan absensi kehadiran siswa. Kemudian siswa dikondisikan untuk siap mengikuti pembelajaran. Guru melakukan apersepsi untuk menggali pengetahuan awal siswa yang berkaitan dengan gayagesek. Lalu menyampaikan tujuan pembelajaran yang akan dicapai pada hari itu yaitu memahami konsep tentang gaya gesek dan pemanfaatannya dalam kehidupan seharihari.

2) Kegiatan Inti

a) Tahap pecobaan awal, guru melakukan demonstrasi untuk menampilkan masalah yang berkaitan dengan materi IPA yang akan dipelajari.

b) Tahap pengamatan, siswa mengamati demonstrasi guru.

c) Tahap hipotesis awal, yaitu siswa diharapkan merumuskan hipotesis awal dari masalah yang didemonstrasikan guru.

d) Tahap verifikasi/ melakukan percobaan, pada tahap ini siswa bekerja dalam kelompoknya masing-masing untuk melakukan eksperimen dengan mengikuti langkah-langkah yang terdapat dalam LKK, mengamati percobaan yang dilakukan, menjawab pertanyaan arahan dalam LKK, dan membuat kesimpulan dari hasil percobaan yang dilakukan. Guru mengawasi dan membimbing siswa dalam melakukan eksperimen, sambil mengisi format penilaian observasi yang telah disiapkan. Setelah LKK selesai dikerjakan, guru memberikan kesempatan kepada perwakilan kelompok untuk melaporkan hasil percobaannya.

e) Tahap evaluasi, guru membagikan soal postes kepada setiap individu. Nilai tes tersebut dijadikan sebagai bahan untuk merefleksi pembelajaran yang telah dilaksanakan untuk perbaikan pada siklus berikutnya jika target penelitian belum tercapai.

3) Kegiatan Akhir

Menyimpulkan materi pelajaran yang telah dipelajari, guru memberi penguatan positif, dan berdoa bersama untuk menutup pembelajaran.

\section{c. Observasi Tindakan Siklus II}

Berdasarkan observasi pada tindakan siklus II diperolah data aktivitas siswa dengan menerapkan metode eksperimen yaitu sebagai berikut: serius dalam mengikuti pembelajaran $77,3 \%$, mengamati demonstrasi guru $73,3 \%$, mengajukan pertanyaan $64 \%$, mengutarakan jawaban 66\%, aktif berpartisipasi dalam kelompok $72,7 \%$, melakukan eksperimen sesuai dengan langkah kerja $70 \%$, menggunakan media pembelajaran $73,3 \%$, mengamati percobaan yang dilakukan $68 \%$, aktif berdiskusi dalam kelompok $68,7 \%$, dan mengerjakan tes secara individu $79,3 \%$. Berdasarkan data tersebut, nilai rata-rata keseluruhan aktivitas siswa dengan menerapkan metode eksperimen mencapai $71,3 \%$ artinya sudah termasuk dalam kategori baik.

Hasil nilai pemahaman konsep siswa setelah penerapan metode eksperimen pada siklus II diuraikan sebagai berikut: indikator pemahaman menjelaskan tercapai $78,9 \%$, indikator mencontohkan tercapai $75 \%$, indikator menafsirkan tercapai $71,7 \%$, indikator membandingkan tercapai $75 \%$ dan indikator menyimpulkan tercapai $73,3 \%$. Dari hasil postes pemahaman konsep pada siklus II sudah memperoleh hasil yang baik, semua indikator pemahaman tercapai $\geq 70 \%$.

Adapun nilai rata-rata hasil tes pemahaman konsep setelah menggunakan metode eksperimen pada siklus II adalah sebesar 75,3 dengan ketuntasan klasikal sebeesar 86,7\%. Sementara itu, hasil pengamatan yang 
dilakukan untuk mengukur kinerja guru pada siklus II ini sudah termasuk kategori baik dengan persentase $82,7 \%$.

d. Refleksi Siklus II

Berdasarkan hasil observasi setelah melakukan tindakan pada siklus II diketahui bahwa penerapan metode eksperimen untuk meningkatkan pemahaman konsep siswa telah menunjukkan hasil yang signifikan. Secara keseluruhan terjadi peningkatan yang sangat baik dari siklus sebelumnya. Dalam melakukan percobaan siswa sudah mulai terbiasa dan tidak terlihat ragu-ragu lagi, sebagian besar siswa dapat menyelesaikan soal pemahaman dengan baik, siswa sudah mulai aktif dan berani dalam mengajukan dan menjawab pertanyaan, serta dilihat dari pencapaian secara klasikal sudah mencapai $86,7 \%$. Dengan kata lain, penelitian dapat dikatakan telah berhasil mencapai tujuan yang diharapkan dan tidak dilanjutkan pada siklus selanjutnya.

C. Pembahasan Hasil Penelitian

1. Aktivitas siswa dalam pembelajaran IPA materi gaya dengan menerapkan metode eksperimen, berdasarkan hasil observasi yang telah dilakukan, dapat dilihat adanya peningkatan nilai ratarata aktivitas, yaitu pada siklus I sebesar 66,8\% dengan kategori Cukup, kemudian meningkat pada siklus ke II menjadi $71,3 \%$ artinya sudah termasuk dalam kriteris Baik. Peningkatan ini terjadi karena adanya keterlibatan siswa dalam proses pembelajaran, siswa melakukan percobaan sendiri, mengamti prosesnya, dan menuliskan hasil dari percobaannya. Sejalan dengan pengertian metode eksperimen menurut Djamarah (2006, hlm. 84), "Metode eksperimen merupakan cara penyajian pelajaran, dengan cara siswa melakukan dan membuktikan sendiri apa yang dipelajari”.
2. Pemahaman konsep siswa terhadap pembelajaran IPA materi gaya setelah menerapkan metode eksperimen mengalami peningkatan yang optimal daripada siklus sebelumnya. Berdasarkan hasil perbandingan nilai tes pemahaman konsep gaya pada siklus I dan siklus II. Hal ini dilihat dari adanya peningkatan nilai rata-rata siswa dan ketuntasan siswa secara klasikal. Secara rinci dapat dilihat pada Tabel 2.

\begin{tabular}{|c|c|c|}
\hline Kriteria & Siklus I & Siklus II \\
\hline $\begin{array}{l}\text { Nilai } \\
\text { Terendah }\end{array}$ & 20 & 40 \\
\hline $\begin{array}{l}\text { Nilai } \\
\text { Tertinggi }\end{array}$ & 100 & 100 \\
\hline $\begin{array}{l}\text { Nilai Rata- } \\
\text { rata }\end{array}$ & 68,3 & 75,3 \\
\hline $\begin{array}{l}\text { Jumlah } \\
\text { siswa tuntas } \\
\text { KKM }\end{array}$ & 20 & 26 \\
\hline $\begin{array}{l}\text { Jumlah } \\
\text { siswa belum } \\
\text { tuntas }\end{array}$ & 10 & 4 \\
\hline $\begin{array}{l}\text { Persentase } \\
\text { Ketuntasan }\end{array}$ & $66,7 \%$ & $86,7 \%$ \\
\hline
\end{tabular}

Berdasarkan tabel 2. dapat dilihat terjadi peningkatkan dari siklus I ke siklus II, nilai rata-rata siswa meningkat sebeesar 7 poin dari siklus I 68,3 pada siklus II menjadi 75,3. Selain itu, persentase ketuntasan klasikalpun meningkat dengan signifikan. Pada siklus I hanya66,7\% lalu meningkat sebesar $20 \%$ pada siklus II menjadi $86,7 \%$. Sehingga dapat dikatakan tujuan pembelajaran telah tercapai karena telah mencapai target ketuntasan klasikal hasil tes pemahaman konsep siswa pada tahap perencanaan yaitu sebesar $85 \%$.

Peningkatan tidak hanya dilihat dari nilai rata-rata dan persentase ketuntasan klasikal siswa, namun dilihat juga dari persentase pencapaian siswa terhadap setiap indikator pemahaman konsep yang diukur dalam penelitian ini. Lebih jelas dapat dilihat pada Tabel 3. 
Tabel 3. Rekapitulasi Nilai Hasil Tes Pemahaman pada Tiap Indikator

\begin{tabular}{ccc}
\hline Indikator & \multicolumn{2}{c}{ Persentase } \\
\cline { 2 - 3 } Pemahaman & Siklus I & Siklus II \\
\hline Menjelaskan & $70 \%$ & $78,9 \%$ \\
\hline Mencontohkan & $70 \%$ & $75 \%$ \\
\hline Menafsirkan & $58,3 \%$ & $71,7 \%$ \\
\hline Membandingkan & $73,3 \%$ & $75 \%$ \\
\hline Menyimpulkan & $76,7 \%$ & $73,3 \%$ \\
\hline Rata-rata & $69,6 \%$ & $74,8 \%$ \\
\hline
\end{tabular}

Berdasarkan Tabel 3. menunjukan bahwa pada siklus pertama masih ada indikator yang pencapaiannya kurang dari $60 \%$, sedangkan pada siklus kedua persentase pada setiap indikator pemahaman konsep sudah melebihi $60 \%$ semua, sehingga dapat dikatakan bahwa peningkatan pemahaman konsep pada setiap indikator dengan menerapkan metode eksperimen ini telah berhasil.

Peningkatan ini menjadi bukti bahwa metode eksperimen dapat digunakan untuk meningkatkan pemahaman konsep siswa pada pembelajaran IPA mengenai materi gaya di SD. Hal ini dikarenakan dengan menggunakan metode eksperimen siswa dilatih melatih dan diajarkan untuk belajar konsep suatu materi yang sedang dipelajari dengan cara melakukan percobaan sendiri. Roestiyah (2008, hlm. 80) menegaskan bahwa "Metode eksperimen mempunyai tujuan supaya siswa dapat mencari dan menemukan bukti kebenaran dari teori tentang sesuatu yang sedang dipelajarinya".

\section{KESIMPULAN}

Berdasarkan hasil penelitian tindakan kelas pada proses pembelajaran dengan menerapkan metode eksperimen di kelas V SD Negeri Legokhuni untuk meningkatkan pemahaman konsep siswa dalam pembelajaran IPA materi gaya yang dilaksanakan sebanyak dua siklus, diperoleh kesimpulan sebagai berikut:
1. Aktivitas siswa dalam proses pembelajaran IPA materi gaya dan pemanfaatannya dengan menerapkan metode eksperimen menunjukkan adanya peningkatan. Hal ini terlihat dari aspek kemampuan merumuskan hipotesis, melakukan percobaan, mengamati percobaan, dan mengerjakan soal evaluasi yang telah telah meningkat dari siklus I ke ssiklus II. Pada siklus I rata-rata nilai persentase aktivitas siwa sebesar $66,8 \%$ yang artinya termasuk dalam kriteria Cukup, lalu pada siklus II meningkat menjadi $71,3 \%$ yang artinya sudah termasuk dalam kriteria Baik.

2. Pemahaman konsep siswa pada pembelajaran materi gaya dan pemanfaatannya setelah menerapkan metode eksperimen mengalami peningkatan yang signifikan. Dibuktikan dengan nilai rata-rata hasil postes dan persentase ketuntasan klasikal siswa yang diperoleh dalam setiap siklusnya yang meningkat. Pada siklus I nilai rata-rata siswa adalah 68,3 dengan persentase ketuntasan klasikal $66,7 \%$. Pada siklus II nilai rata-rata meningkat menjadi 75,3 dengan persentase ketuntasan $86,7 \%$. Hal ini mengindikasikan bahwa tujuan pembelajaran yang telah direncanakan telah tercapai yaitu mencapai ketuntasan klasikal $\geq 85 \%$.

Dengan demikian, dapat disimpulkan secara umum bahwa penerapan metode eksperimen dalam pembelajaran IPA materi gaya dan pemanfaatannya terbukti dapat meningkatkan pemahaman konsep siswa.

\section{DAFTAR RUJUKAN}

Anderson, L., dan Krathwohl, D. (2010). Kerangka landasan untuk pembelajaran, pengajaran, dan assesmen. Yogyakarta: Pustaka Belajar. 
Aqib, dkk. (2010). Penelitian Tindakan

Kelas. Bandung: Yrama Widya.

Depdiknas. (2006). Model kurikulum tingkat satuan pendidikan SD dan MI. Solo: Tiga Serangkai.

Djamarah, S, B., dan Zain, A. (2006). Strategi Belajar Mengajar. Jakarta: Rineka Cipta.

Hamdayama, J. (2014). Model dan Metode Pembelajaran Kreatif dan Berkarakter. Bogor: Ghalia Indonesia

K. Roestiyah, N. (2008). Strategi Belajar Mengajar. Jakarta: Rineka Cipta. Ramyulis. (2005). Langkah-langkah metode eksperimen. Bandung: Angkasa Bandung.

Sagala, S. (2005). Konsep dan makna pembelajaran. Bandung: CV. Alfabeta.

Samatowa, U. (2010). Pembelajaran IPA di Sekolah Dasar. Jakarta: Indeks.

Sudjana. (2006). Penilaian Hasil Proses Belajar Mengajar. Bandung: Remaja Rosdakarya.

Sugiyono. (2009). Metode Penelitian Kuantitatif, Kualitatif, dan $R \& D$. Bandung: Alfabeta.

Tsuraya, N, M. (2013). Penerapan metode eksperimen untuk meningkatkan pemahaman konsep siswa dalam pembelajaran IPA di Sekolah Dasar. Skripsi. Program Sarjana Universitas Pendidikan Indonesia, Kampus Purwakarta.

Widodo, A. (2006). Taksonomi Bloom dan Pengembangan Butir Soal. Buletin Puspendik, 3 (2), hlm.18-29. 